\title{
Reproductive biology and sexual dimorphism in Cnemidophorus vacariensis (Sauria, Teiidae) in the grasslands of the Araucaria Plateau, southern Brazil
}

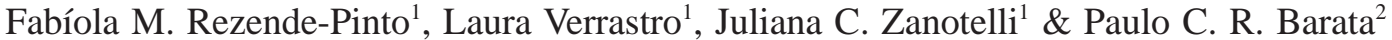

1. Programa de Pós-Graduação em Biologia Animal, Departamento de Zoologia, Universidade Federal do Rio Grande do Sul, Av. Bento Gonçalves 9500, bloco IV, prédio 43435, sala 102, 91501-970 Porto Alegre, RS, Brazil. (fabiola_rezende@yahoo.com.br) 2. Fundação Oswaldo Cruz, Rua Leopoldo Bulhões 1480-8A, 21041-210 Rio de Janeiro, RJ, Brazil.

\begin{abstract}
The reproductive cycle and sexual dimorphism of the lizard Cnemidophorus vacariensis Feltrim \& Lema, 2000 were studied on the basis of data gathered between August 2004 and August 2006 in Vacaria, Rio Grande do Sul, Brazil. Snout-vent length (SVL) of sexually mature males varied between 48.8 and $72.9 \mathrm{~mm}(\bar{x}=63.3 \pm 6.0 \mathrm{~mm} ; \mathrm{n}=76)$ and, for females, between 57.4 and 81.8 $\mathrm{mm}(\bar{x}=70.0 \pm 5.9 \mathrm{~mm} ; \mathrm{n}=73)$. Other morphological characteristics were also compared between sexes. Reproduction was seasonal, and observations indicate two clutches in the same reproductive season. Clutch size and other reproductive characteristics were analyzed as well as the relation between reproduction and environmental factors. Cnemidophorus vacariensis is apparently endemic to highland plateaus in southern Brazil and has been classified as vulnerable on some lists of threatened fauna in this country. Some suggestions for conservation measures are presented, due to the observed degradation of this species' environment.
\end{abstract}

KEYWORDS. Teiidae, Cnemidophorus vacariensis, reproduction, sexual dimorphism, conservation.

RESUMO. Biologia reprodutiva e dimorfismo sexual em Cnemidophorus vacariensis (Sauria, Teiidae) nos campos do Planalto das Araucárias, sul do Brasil. O ciclo reprodutivo e o dimorfismo sexual do lagarto Cnemidophorus vacariensis Feltrim \& Lema, 2000 foram estudados com base em dados coletados de agosto de 2004 a agosto de 2006, em Vacaria, Rio Grande do Sul, Brasil. O comprimento rostro-cloacal dos machos sexualmente maduros variou de 48,8 a $72,9 \mathrm{~mm}(\bar{x}=63,3 \pm 6,0 \mathrm{~mm} ; \mathrm{n}=76)$ e, das fêmeas, de 57,4 a $81,8 \mathrm{~mm}(\bar{x}=70,0 \pm 5,9 \mathrm{~mm} ; \mathrm{n}=73)$. Outras características morfológicas também foram comparadas entre os sexos. A reprodução foi sazonal, e houve evidências de duas desovas em uma mesma temporada reprodutiva. Foram analisados o tamanho da desova e outras características reprodutivas, assim como a relação entre a reprodução e fatores ambientais. Cnemidophorus vacariensis é aparentemente endêmico dos campos de altitude do sul do Brasil e está registrado como vulnerável em algumas listas de fauna ameaçada do país. São apresentadas algumas sugestões de medidas de conservação, em função da degradação observada do ambiente em que vive esta espécie.

PALAVRAS-CHAVE. Teiidae, Cnemidophorus vacariensis, reprodução, dimorfismo sexual, conservação.

Several studies have analyzed the reproductive strategies and sexual dimorphism in lizards of the family Teiidae (e.g. VitT, 1983; Magnusson, 1987; ANDERson \& VitT, 1990; VitT \& Breitenbach, 1993; CruZ et al., 1999). When evaluating reproductive characteristics of lizards, it is important to take into account possible sources of variation in their life histories (BALLINGER, 1983). In addition to environmental variables, geographic factors and seasonality patterns, characteristics such as foraging habit (Huey \& PianKa, 1981; VitT, 1990), morphology and escape reaction (VITT \& ConGDON, 1978), phylogeny (DuNHAM \& Miles, 1985), and mortality patterns generally affect the reproductive characteristics of lizards and should be considered when investigating general patterns of their life history.

Until recently, the genus Cnemidophorus Wagler, 1830 was considered to be composed of about 60 species, distributed from the north of the United States to central Argentina (WRIGHT, 1993). Based on a combination of mitochondrial DNA, morphological and allozyme analyses, REEDER et al. (2002) reformulated the phylogenetic relationships among species of Cnemidophorus. All analyzed species from North America were placed in the genus Aspidoscelis Fitzinger, 1843. A total of 10 species of Cnemidophorus have been recorded for Brazil (Sociedade Brasileira de Herpetologia, 2005).
Cnemidophorus vacariensis Feltrim \& Lema, 2000 lives in rocky environments in plateau grasslands with altitude in the range of 900-1400 m. Its known distribution is restricted to a few localities (1) in the State of Rio Grande do Sul: in the municipalities of Vacaria, Bom Jesus (DIBernardo et al., 2003) and São Francisco de Paula (STAHNKE et al., 2006); (2) in the State of Santa Catarina: in the municipality of Capão Alto (F. M. Rezende-Pinto, unpublished data); and (3) in the state of Paraná: in the municipality of Candói (BÉRNILs et al., 2004). This lizard species is apparently endemic to the Araucaria Plateau of southern Brazil.

Field observations have demonstrated that $C$. vacariensis has diurnal habits and is active during the whole year, differing from other species of the family Teiidae which hibernate when environmental conditions are not favorable (e.g. CRUz et al., 1999), and also that they dig burrows under stones in sandy substrates. Unpublished data suggest that $C$. vacariensis is a thigmothermic lizard (D. M. Machado, pers. comm.), feeding mainly on spiders, grasshoppers, and cockroaches (M. Schossler, pers. comm.).

Cnemidophorus vacariensis is recorded as vulnerable in the Official Lists of endangered fauna of Rio Grande do Sul (MARques et al., 2002; Di-Bernardo et al., 2003) and Paraná (BérniLs et al., 2004), and also in the 
National List (Instituto Brasileiro do Meio Ambiente e dos Recursos Naturais Renováveis, 2003), due to the paucity of data on this species and the considerable degradation of its habitat, which has been mainly threatened by cattle ranching, plantation (soy and apple), clearing of the land by burning, and reforestation by introduced Pinus species. Therefore studies on the biological, ecological, and behavioral characteristics of C. vacariensis are needed to guide the management and conservation of this species and its habitat.

This is the first published article on the biology of C. vacariensis; its main goal is to study the reproductive cycle and sexual dimorphism of the species. The following questions are addressed: (1) Are the reproductive activity and cycles of stored fat seasonal or continuous? (2) What is the reproductive cycle of males and females? (3) At which snout-vent length (SVL) do males and females reach sexual maturity? (4) What is the effect of environmental factors (temperature, photoperiod, precipitation) on the reproductive activity and body fat cycles? (5) What is the clutch size? (6) Does clutch size depend on female size? (7) Is there any sexual dimorphism in morphological characteristics and in the coloration pattern?

\section{MATERIAL AND METHODS}

Study area and data collection. The study area (28 $33^{\prime} \mathrm{S}, 50^{\circ} 42^{\prime} \mathrm{W}$ ) was located in the municipality of Vacaria, Rio Grande do Sul, Brazil, in the grasslands of the Araucaria Plateau, at an altitude of about $950 \mathrm{~m}$. It has a humid temperate climate, with mean annual temperature of $15.2^{\circ} \mathrm{C}$ and mean temperature of the coldest month of $10.6^{\circ} \mathrm{C}$; mean annual precipitation is about $1400 \mathrm{~mm}$ (MALuf, 2000). The soil in that region originated from basaltic rock over arenite (FORTES, 1959). Two main types of vegetation are found in the region: a mixed ombrophilous forest (composed of species associated with Araucaria angustifolia Araucariaceae) and grasslands (with a uniform landscape but presenting high species diversity) (BOLDRINI, 1997).

Fieldwork was carried out between August 2004 and August 2006; in that period, a total of 249 individuals (100 juveniles, 73 mature females, and 76 mature males) were collected by hand in rocky outcrops located in the grasslands. Animals were weighed using a dynamometer (accuracy $=0.1$ or $0.25 \mathrm{~g})$, immediately killed with ketamine-based veterinary anesthetic, and measured with calipers (accuracy $=0.02 \mathrm{~mm}$ ). Animals were preserved with formalin $10 \%$, kept in alcohol $70 \%$, and deposited in the Scientific Collection of Herpetology of the Department of Zoology of Universidade Federal do Rio Grande do Sul (UFRGS). In the laboratory, the right ovaries, testicles, and epididymides were removed for preparation of histological sections to be used in the analysis of gonadal and sexual maturation cycles. Gonads were prepared in blocks of paraffin wax to make sections of $7 \mu \mathrm{m}$ in thickness, which were stained with haematoxylin-eosin.

Both fat bodies (FBs) were extracted from each animal and weighed with a precision scale $(0.00001 \mathrm{~g})$. Because the mass of the FBs was weakly dependent on the SVL in both sexes (males: $\mathrm{r}^{2}=0.25 ; \mathrm{p}<0.0001$; females: $\left.\mathrm{r}^{2}=0.11 ; \mathrm{p}<0.0001\right)$ and on the body mass (males: $\mathrm{r}^{2}=$ $0.22 ; \mathrm{p}<0.0001$; females: $\left.\mathrm{r}^{2}=0.21 ; \mathrm{p}<0.0001\right)$, that mass was expressed in absolute values.

Statistical analyses (linear models). In the statistical analyses involving linear models with one dependent variable, for each analysis the statistical model used for the inferences was selected among alternative linear models (some of them including interactions between the independent variables) by means of the Akaike information criterion (AIC). The linear model that presented the lowest value of AIC was chosen for the analyses (Wood, 2006). In analyses having SVL and sex as independent variables, when a model with interaction between sex and SVL was selected, the method of Johnson-Neyman was used for determining the region of values of SVL in which there was a significant difference in the dependent variable between sexes (РоттноғF, 1983). Continuous variables used in linear models (as well as in $t$ tests) were tested for normality using KolmogorovSmirnov tests and Q-Q plots (VerZANI, 2005).

Reproduction. The smallest values of SVL of sexually mature males (with sperm in the lumen of the seminal tubes and/or in the epididymides) and of sexually mature females (with vitellogenic follicles (VFs) and/or eggs in the oviducts) were taken as the SVL at which animals reach sexual maturity in each sex.

In males, monthly gonadal activity was analyzed by means of the volume of the testis, calculated using the formula for the volume of the ellipsoid: $V=4 / 3 \pi a b^{2}$, where $a$ is $1 / 2$ of the length of the longest axis and $b$ is $1 / 2$ of the largest width of the testis. The influence of SVL was not considered in the analyses of the testis' volume, because a linear regression explained only $24.5 \%$ of the volume variation $(\mathrm{p}<0.0001)$. The characterization of the reproductive cycle of the females was based on the presence of VFs and/or eggs in the oviducts. Follicles were considered vitellogenic when presenting a yellow color and minimum size of about $3 \mathrm{~mm}$ in diameter. Females were classified as non-reproductive (without VFs or eggs in the oviducts) or reproductive (with VFs and/or eggs in the oviducts). Clutch size was calculated as the number of VFs or eggs in the oviducts; the analyses of its relationship with SVL was performed using a linear model. The number of clutches per reproductive season was estimated by the presence of VFs found simultaneously with eggs in the oviducts or with corpora lutea. The relative clutch mass was estimated as the total egg mass (eggs preserved in alcohol) divided by the total mass of the female (with whole tail) before fixation (VITT, 1990). The volume of an egg in the oviduct was estimated using the geometrical formula for the ellipsoid.

Means of fat bodies of males and females were compared using the $t$ test (VERZANI, 2005).

Data on temperature and precipitation were gathered by the meteorological station located in the municipality of Bom Jesus (located about $50 \mathrm{~km}$ from the study area) and were obtained from the 8 th Meteorological Division of Brazil's National Institute of Meteorology. Data on photoperiod were obtained from the U.S. Naval Observatory (2007).

To analyze the temporal variation of each reproductive variable in the study period, we initially constructed an artificial time series spanning six years 
by replicating the original data, on the assumption that the temporal pattern of the original time series would be repeated every two years. A nonparametric regression was then calculated using the loess method, with local fitting by a second degree polynomial; in each case, the smoothing parameter was some fixed number between 0.12 and 0.15 . Pointwise $95 \%$ confidence intervals for the regression curve were also computed by the loess method (Cleveland et al., 1993).

Sexual dimorphism. The following biometric variables were measured in adults: snout-vent length (SVL); head height $(\mathrm{HH})$, measured at the highest point of the head; head length (HL), distance from the rostral scale to the posterior border of the post-parietal scales; head width (HW), measured at the widest portion of the head just behind the mandible; width of the buccal commissure (WBC); distance between axilla and groin (AG); length of the anterior limb (LAL), distance from the insertion of the limb to the tip of the longest finger; length of the posterior limb (LPL), distance from the insertion of the limb to the tip of the longest toe; tail length (TL), distance from the posterior border of the cloaca to the tip of the tail; and tail base width (TBW), measured just below the cloaca.

To compare SVL of adult males and females, the $t$ test was used. To deal with morphometric measurements in a relative way (REIST, 1985), a linear regression was performed between each biometric variable and SVL, and also between mass and SVL; the residuals obtained from the regressions concerning the variables $\mathrm{HH}, \mathrm{HL}, \mathrm{HW}$, WBC, AG, LAL, LPL, and mass were then used in a MANOVA (JoHNSON \& WICHERN, 2002) to analyze differences in body shape between sexes. Since some animals presented regenerated tails, and only some measurements of TBW were performed before the animals were fixed, we did not include the variables TL and TBW in the MANOVA. Kolmogorov-Smirnov tests, graphical analyses using Q-Q plots, and analyses of regression's residuals (VERZANI, 2005) indicated that it was not necessary to log-transform morphological variables to get closer to normal distributions and to stabilize variances. The analyses of the relationship between HL, AG, TL and TBW and the variables SVL and sex were performed using linear models.

The color of scales in the first and second ventral longitudinal rows was recorded for adult males $(n=42)$, adult females $(n=33)$ and juveniles $(n=22)$ before animals were fixed.

Statistical analyses were performed using the software R 2.4.1 (R DEVELOPMENT CORE TEAM, 2006), with level of significance of 0.05 . Means \pm 1 standard deviation $(\bar{x} \pm 1 \mathrm{SD})$ are reported in the text.

Examined samples: BRASIL, Rio Grande do Sul: Vacaria

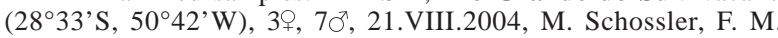
Rezende-Pinto, J. C. Zanotelli \& D. M. Machado cols. (UFRGS 3684-3693); 3, 7o', 18.IX.2004, M. Schossler, F. M. RezendePinto, J. C. Zanotelli \& D. M. Machado cols. (UFRGS 36963705); 7ㅇ, 30', 23.X.2004, M. Schossler, F. M. Rezende-Pinto, J. C. Zanotelli \& D. M. Machado cols. (UFRGS 3746-3755); 29, 307, 27 XI.2004, M. Schossler, F. M. Rezende-Pinto, J. C. Zanotelli \& D. M. Machado cols. (UFRGS 3757-3761); 4, 20', 27.XI.2004, M. Schossler, F. M. Rezende-Pinto, J. C. Zanotelli \& D. M. Machado cols. (UFRGS 3763-3768); 69, 40', 11.XII.2004, M. Schossler, F. M. Rezende-Pinto, J. C. Zanotelli \& D. M. Machado cols. (UFRGS 3771-3780); 69, 30', 22.I.2005, M. Schossler, F. M. RezendePinto, J. C. Zanotelli \& D. M. Machado cols. (UFRGS 3788-
3796); 99, 30, 19.II.2005, M. Schossler, F. M. Rezende-Pinto, J. C. Zanotelli \& D. M. Machado cols. (UFRGS 3814-3825); 59, $50^{\circ}$, 19.III.2005, M. Schossler, F. M. Rezende-Pinto, J. C. Zanotelli \& D. M. Machado cols. (UFRGS 3847-3856); 6ㅇ, o’, 31.III.2005, M. Schossler, F. M. Rezende-Pinto, J. C. Zanotelli \& D. M. Machado cols. (UFRGS 3861-3867); 5, 60', 16.IV.2005, M. Schossler, F. M. Rezende-Pinto, J. C. Zanotelli \& D. M. Machado cols. (UFRGS 3868-3878); B\&, 21.V.2005, M. Schossler, F. M. Rezende-Pinto, J. C. Zanotelli \& D. M. Machado cols. (UFRGS 3882); + , 21.V.2005, M. Schossler, F. M. Rezende-Pinto, J. C. Zanotelli \& D. M. Machado cols. (UFRGS 3883); 7ㅇ, 30', 21.V.2005, M. Schossler, F. M Rezende-Pinto, J. C. Zanotelli \& D. M. Machado cols. (UFRGS 3885-3894); 4ㅇ, 50', 18.VI.2005, M. Schossler, F. M. RezendePinto, J. C. Zanotelli \& D. M. Machado cols. (UFRGS 3908 3916); 8 , $50^{\top}$, 23.VII.2005, M. Schossler, F. M. Rezende-Pinto, J. C. Zanotelli \& D. M. Machado cols. (UFRGS 3924-3936); 69, 70?, 21.VIII.2005, M. Schossler, F. M. Rezende-Pinto, J. C. Zanotelli \& D. M. Machado cols. (UFRGS 3939-3951); 8, 40', 17.IX.2005, M. Schossler, F. M. Rezende-Pinto, J. C. Zanotelli \& D. M. Machado cols. (UFRGS 3954-3965); 4, o', 08.X.2005, M. Schossler, F. M Rezende-Pinto, J. C. Zanotelli \& D. M. Machado cols. (UFRGS 3968-3972); 2, 50'08.X.2005, M. Schossler, F. M. RezendePinto, J. C. Zanotelli \& D. M. Machado cols. (UFRGS 39743980); 4ㅇ, 7o', 26.XI.2005, M. Schossler, F. M. Rezende-Pinto, J. C. Zanotelli \& D. M. Machado cols. (UFRGS 4000-4010); 6ㅇ, 407, 17.XII.2005, M. Schossler, F. M. Rezende-Pinto, J. C. Zanotelli \& D. M. Machado cols. (UFRGS 4022-4031); 39, o', 10.I.2006, M. Schossler, F. M. Rezende-Pinto, J. C. Zanotelli \& D. M. Machado cols. (UFRGS 4033-4036); 69, 60', 09.II.2006, M. Schossler, F. M. Rezende-Pinto, J. C. Zanotelli \& D. M. Machado cols. (UFRGS 4037-4048); +, 7ठ, 31.III.2006, M. Schossler, F. M. RezendePinto, J. C. Zanotelli \& D. M. Machado cols. (UFRGS 40494056); 29, 40’, 30.IV.2006, M. Schossler, F. M. Rezende-Pinto, J. C. Zanotelli \& D. M. Machado cols. (UFRGS 4128-4133); 39, 30.IV.2006, M. Schossler, F. M. Rezende-Pinto, J. C. Zanotelli \& D. M. Machado cols. (UFRGS 4135-4137); 39, 40, 12.V.2006, M. Schossler, F. M. Rezende-Pinto, J. C. Zanotelli \& D. M. Machado cols. (UFRGS 4138-4144); 29, 50', 24.VI.2006, M. Schossler, F. M. Rezende-Pinto, J. C. Zanotelli \& D. M. Machado cols. (UFRGS 4149-4155); ㅇ, 4ठ', 21.VII.2006, M. Schossler, F. M. RezendePinto, J. C. Zanotelli \& D. M. Machado cols. (UFRGS 42164220); 29, 30', 18.VIII.2006, M. Schossler, F. M. Rezende-Pinto, J. C. Zanotelli \& D. M. Machado cols. (UFRGS 4242-4246).

\section{RESULTS}

Reproductive cycle. The SVL of sexually mature males varied between 48.8 and $72.9 \mathrm{~mm}(\bar{x}=63.3 \pm 6.0 \mathrm{~mm}$; $\mathrm{n}=76$ ). No males with SVL larger than $48.8 \mathrm{~mm}$ were observed without spermatozoids in the seminal tubes or epididymides during the reproductive period. The smallest reproductive female had SVL of $57.4 \mathrm{~mm}$, and had two VFs, one in each ovary. All females with SVL larger than $57.4 \mathrm{~mm}$ were mature during the reproductive season. The SVL of sexually mature females varied between 57.4 and $81.8 \mathrm{~mm}(\bar{x}=70.0 \pm 5.9 \mathrm{~mm} ; \mathrm{n}=73)$ (Tab. I).

All variables, except precipitation, showed a statistically significant variation in the study period, since the mean in the two-year period, in some months, was outside the pointwise $95 \%$ confidence intervals. With regard to precipitation, its monthly mean value was always inside the pointwise $95 \%$ confidence intervals in the first year; in the second year, there was significant variation, and precipitation was higher (albeit by a relatively slight margin) in September/October, and lower in April/May (Fig. 1).

There were annual reproductive cycles in the study period (Fig. 1). The peak of the reproductive cycle of males coincided with the peak of the female reproductive cycle. The testicular volume was highest in October/ 
November $\left(\bar{x}=72.2 \pm 29.6 \mathrm{~mm}^{3} ; \mathrm{n}=17\right)$, and lowest in February $\left(\bar{x}=8.9 \pm 2.1 \mathrm{~mm}^{3} ; \mathrm{n}=6\right)$; females were able to reproduce between October and December, and they were nonreproductive between January and September.

In both sexes, the cycle of FBs presented a welldefined pattern, varying over the months (Fig. 1). The peaks of FB mass of males and females also coincided, but they occurred around May/June; therefore there was a six month time lag between the peaks of FB mass and
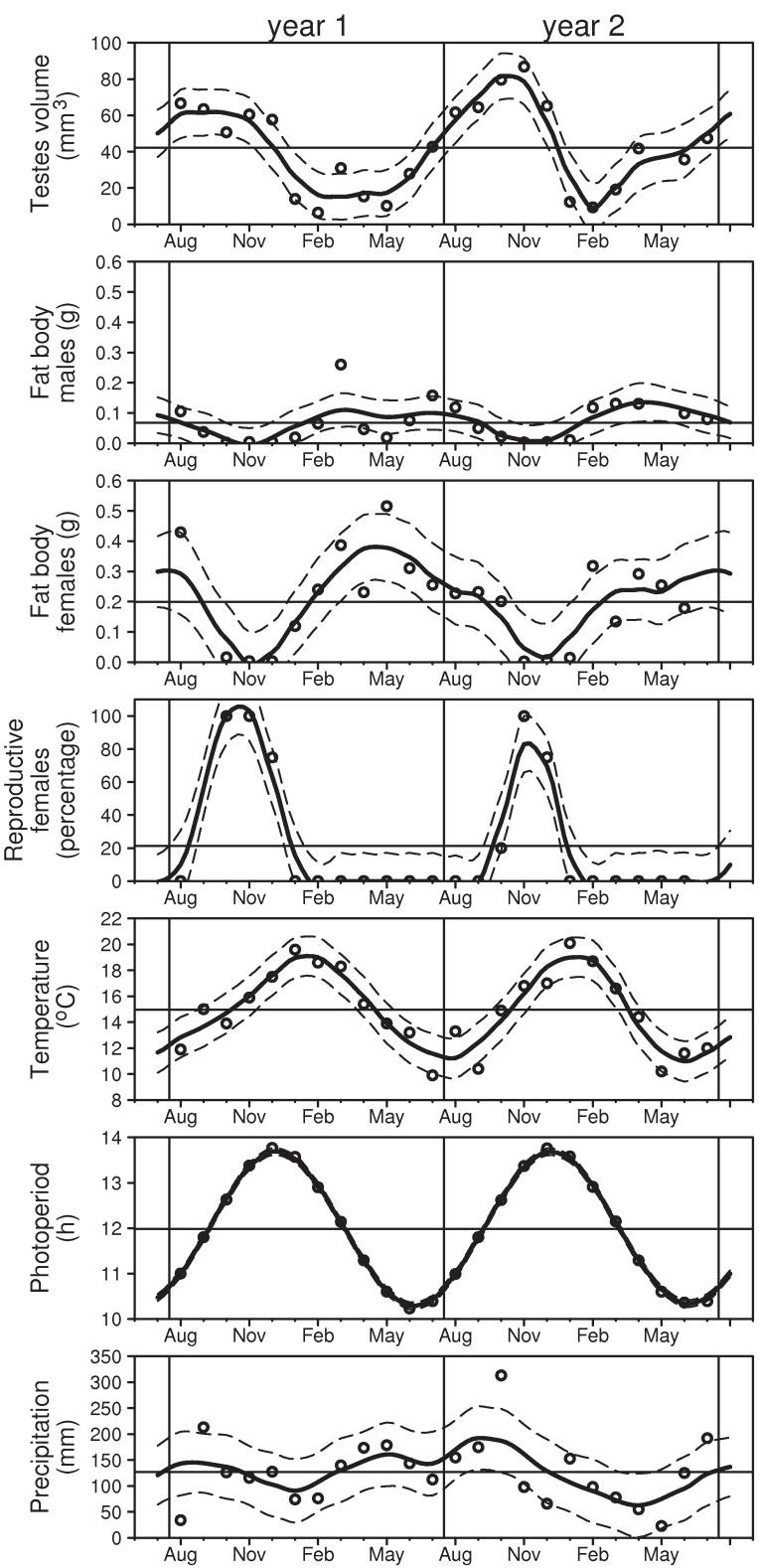

Fig. 1. Cnemidophorus vacariensis Feltrim \& Lema, 2000, August 2004 to July 2006, Vacaria, southern Brazil. Testicular volume $\left(\mathrm{mm}^{3}\right)$, mass of fat bodies of males and females $(\mathrm{g})$, percentage of females in reproductive stage, temperature $\left({ }^{\circ} \mathrm{C}\right)$, photoperiod $(\mathrm{h})$ and precipitation $(\mathrm{mm})$ by month. Thick continuous curves indicate regressions calculated by the loess method; dashed curves on each side indicate pointwise 95\% confidence intervals. Horizontal straight lines indicate the monthly mean of each variable in the two-year period. Note that the graphs concerning the mass of fat bodies of males and females have the same vertical scale, and that, in the graph concerning the photoperiod, the data points and the dashed curves are quite close to the central thick continuous curve. reproductive activity. In males, mean FB mass was smaller during the reproductive period, between September and December; the lowest mean was recorded in OctoberDecember $(\bar{x}=6.36 \pm 8.7 \mathrm{mg} ; \mathrm{n}=25)$. In January, when testicles were empty and presented a reduced volume, fat started to accumulate, and the mass of the FBs increased up to the highest mean mass in March-April $(\bar{x}=126.8 \pm 61.8 \mathrm{mg} ; \mathrm{n}=10)$. In females, mean FB mass decreased sharply after August, attaining its lowest value in November-December $(\bar{x}=3.9 \pm 3.2 \mathrm{mg} ; \mathrm{n}=15)$. At the end of the reproductive period, in January, females started to accumulate fat, and mean FB mass increased up to the highest value in March-May $(\bar{x}=331.3 \pm 162.0 \mathrm{mg} ; \mathrm{n}=14)$. Females had a mean FB mass significantly higher than that of males in the period of the year when FB mass attained its highest values $(t=-4.0947 ; \mathrm{df}=17.77 ; \mathrm{p}<0.001)$.

Photoperiod and temperature varied seasonally, while precipitation did not show a well-defined seasonal pattern during the study period (Fig. 1). There was a temporal relationship between reproductive activity, temperature, and photoperiod. The peak of reproductive activity occurred about two months before the peak of temperature (which occurred in January), and about one month before the peak of photoperiod.

Females with eggs in the oviducts were found in October $2004(n=4)$ and December $2005(n=2)$ (Fig. 2). The size of VFs ranged from 2.9 to $7.9 \mathrm{~mm}(\mathrm{n}=14)$. Eight females presented VFs simultaneously with eggs in the oviducts $(n=1)$ or corpora lutea $(n=7)$, indicating more than one clutch in the same reproductive season. Between January and September, follicles found in all females were small, with size ranging from 1.4 to $2.5 \mathrm{~mm}$. In September 2005, the three nonreproductive females had SVL of 60.7, 67.7 , and $73.5 \mathrm{~mm}$.

The linear model selected to analyze clutch size by SVL and VFs or eggs in the oviducts did not show any statistically significant difference between VFs and eggs in the oviducts. Therefore, data were pooled and a simple linear regression was performed between clutch size and SVL, where SVL explained $69.7 \%$ of clutch size variation $\left(r^{2}=0.697 ; n=21 ; p<0.0001\right)$ (Fig. 3). Mean clutch size estimated by the number of eggs in the oviducts was 4.2 \pm 0.8 ( 3 to $5 ; \mathrm{n}=6)$ and by the number of VFs was $4.1 \pm 1.0$ ( 2 to $6 ; n=15$ ). Mean clutch size for the pooled data was $4.1 \pm 0.9(2$ to $6 ; n=21)$.

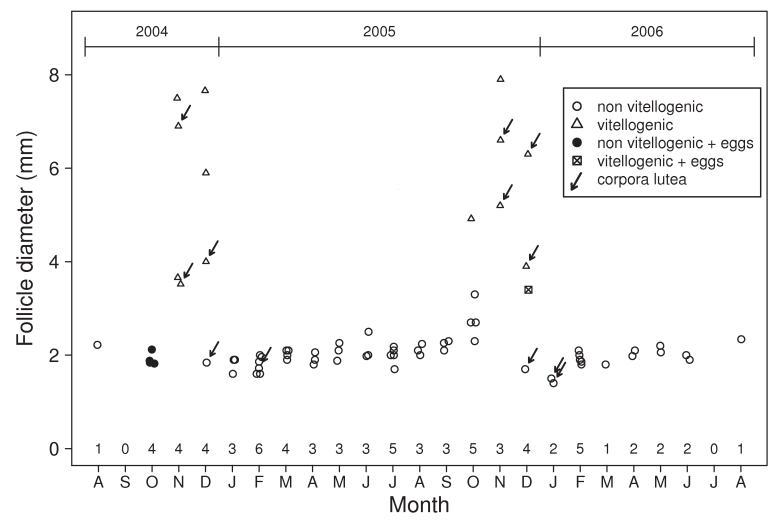

Fig. 2. Monthly distribution of the diameter of the largest follicle by reproductive condition of adult females of Cnemidophorus vacariensis Feltrim \& Lema, 2000, August 2004 to August 2006, Vacaria, southern Brazil. Numbers show monthly sample size. 
The size of 22 eggs found in the oviducts ranged from 10.5 to $15.7 \mathrm{~mm}$ in length, and from 6.1 to $9.0 \mathrm{~mm}$ in width. Mass ranged from 315.9 to $540.5 \mathrm{mg}$, and volume from 227.0 to $638.9 \mathrm{~mm}^{3}$. In December 2005, a clutch with four eggs was found under a stone; the eggs had mean length of $14.7 \pm 0.2 \mathrm{~mm}$, and mean width of $10.9 \pm 0.2 \mathrm{~mm}$. For the three females whose tails did not present any sign of regeneration, the relative mass of eggs in the oviducts was $0.16,0.17$, and 0.22 .

Hatchling recruitment occurred in January and February (Fig. 4). Mean size of hatchlings in these months was $29.1 \pm 0.6 \mathrm{~mm}$ (28.5 to $29.8 \mathrm{~mm}$; $=3$ ).

Sexual dimorphism. Mean SVL of sexually mature C. vacariensis was equal to $66.6 \pm 6.8 \mathrm{~mm}(\mathrm{n}=149)$. The SVL of females was significantly higher than that of males $(\mathrm{t}=6.96 ; \mathrm{df}=146.96 ; \mathrm{p}<0.0001 ; \mathrm{n}=149)$. Eight males presented SVL higher than $69.5 \mathrm{~mm}$, which is the percentile 90 of the SVL of males $(n=76)$, while 40 females had SVL higher than that value. The percentile 90 of the SVL of females was $77.2 \mathrm{~mm}(\mathrm{n}=73)$. The joint mean of the other morphometric variables was significantly different between males and females (MANOVA, $\mathrm{F}_{8,136}=$ 17.43; $\mathrm{p}<0.0001 ; \mathrm{n}=145$ ) (Fig. 4, Tab. I).

The linear model analyzing AG by SVL and sex included the interaction term between SVL and sex ( $\mathrm{p}=$ 0.011 ) and explained $92.5 \%$ of the variation in the data $\left(\mathrm{F}_{3,141}=577.1 ; \mathrm{n}=145 ; \mathrm{p}<0.0001\right)$. According to the Johnson-Neyman method, there was a statistically significant difference in AG between sexes for SVLs higher than $55.5 \mathrm{~mm}$ (Fig. 5). The linear model analyzing HL by SVL and sex included the interaction term between SVL and sex $(\mathrm{p}<0.001)$ and explained $82.7 \%$ of the variation in $\mathrm{HL}\left(\mathrm{F}_{3,141}=224.1 ; \mathrm{n}=145 ; \mathrm{p}<0.0001\right)$. There was a statistically significant difference in HL between sexes for SVLs higher than $51.1 \mathrm{~mm}$ (Fig. 6). The linear model analyzing TL by SVL and sex included the interaction term between SVL and sex $(p=0.004)$ and explained $68.8 \%$ of the variation in TL $\left(\mathrm{F}_{3.98}=72.03 ; \mathrm{n}=\right.$ $102 ; \mathrm{p}<0.0001)$. There was a statistically significant difference in TL between sexes for SVLs higher than 61.0 $\mathrm{mm}$ (Fig. 7). The linear model analyzing TBW by SVL and sex did not include the interaction term between SVL and sex, and explained $63.8 \%$ of variation in TBW $\left(\mathrm{F}_{2,74}=\right.$ $65.26 ; \mathrm{n}=77 ; \mathrm{p}<0.0001)$. TBW varied significantly with SVL for each sex $(\mathrm{p}<0.0001)$, and was higher by $0.77 \mathrm{~mm}$ in males than in females for each SVL ( $<<0.0001)$ (Fig. 8).

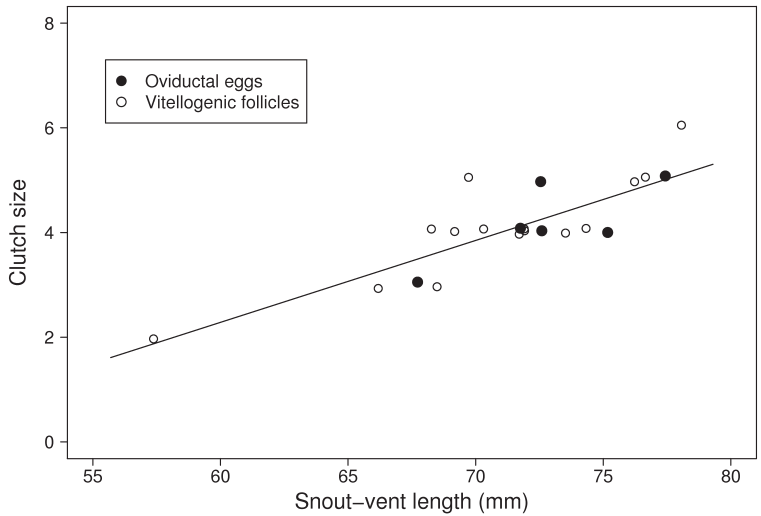

Fig. 3. Clutch size by snout-vent length (SVL) in females of Cnemidophorus vacariensis Feltrim \& Lema, 2000, August 2004 to August 2006, Vacaria, southern Brazil (clutch size = $0.16060 x S V L-7.3835)$

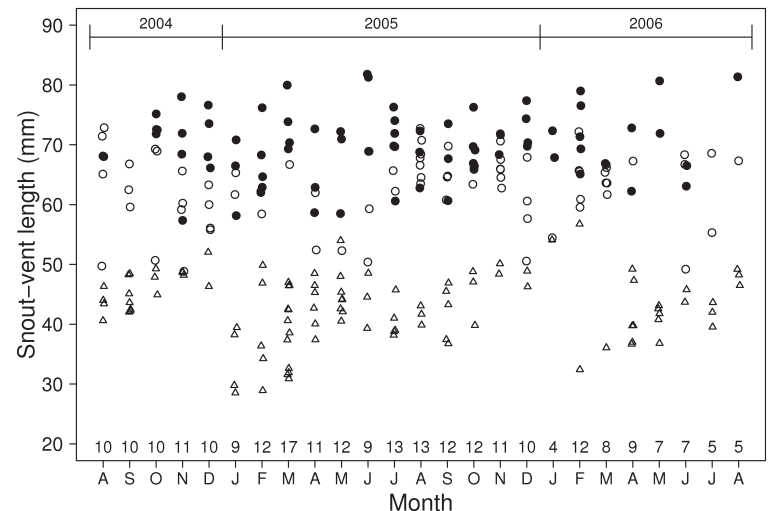

Fig. 4. Monthly distribution of snout-vent length for juveniles, adult males and adult females, Cnemidophorus vacariensis Feltrim \& Lema, 2000, August 2004 to August 2006, Vacaria, southern Brazil. Triangles, juveniles; white circles, males; black circles, females. Numbers indicate monthly sample size.

Table I. Biometric and morphologic characters of adult males (SVL > $48.8 \mathrm{~mm}$ ) and females (SVL > 57.4 mm) of Cnemidophorus vacariensis Feltrim \& Lema, 2000 in the grasslands of the Araucaria Plateau, state of Rio Grande do Sul, Brazil (AG, distance between axilla and groin; HH, height of the head; HL, head length; HW, head width; LAL, length of anterior limb; LPL, length of posterior limb; M, mean; MA, mass (g); Max, maximum; Min, minimum; n, sample size; NFP, number of femoral pores; SD, standard deviation; SVL, snout-vent length; TBW, tail base width; TL, tail length; WBC, width of buccal commissure. Linear measurements are in millimeters).

\begin{tabular}{|c|c|c|c|c|c|c|c|c|}
\hline \multirow[b]{2}{*}{ Variable } & \multicolumn{4}{|c|}{ Males } & \multicolumn{4}{|c|}{ Females } \\
\hline & Min & $\mathrm{M} \pm \mathrm{SD}$ & $\operatorname{Max}$ & $\mathrm{n}$ & Min & $\mathrm{M} \pm \mathrm{SD}$ & $\operatorname{Max}$ & $\mathrm{n}$ \\
\hline SVL & 48.8 & $63.3 \pm 5.99$ & 72.9 & 76 & 57.4 & $70.0 \pm 5.85$ & 81.8 & 73 \\
\hline $\mathrm{HH}$ & 5.4 & $7.9 \pm 0.96$ & 9.8 & 75 & 6.3 & $7.8 \pm 0.66$ & 9.2 & 73 \\
\hline HL & 11.4 & $14.6 \pm 1.38$ & 17.3 & 76 & 12.5 & $14.6 \pm 0.98$ & 16.9 & 72 \\
\hline HW & 7.3 & $10.3 \pm 1.22$ & 12.7 & 76 & 8.4 & $10.1 \pm 0.87$ & 12.4 & 73 \\
\hline WBC & 5.5 & $8.0 \pm 1.24$ & 13.2 & 76 & 6.0 & $7.6 \pm 0.73$ & 9.3 & 73 \\
\hline $\mathrm{AG}$ & 23.2 & $32.3 \pm 3.38$ & 38.2 & 76 & 30.8 & $38.1 \pm 3.82$ & 46.2 & 73 \\
\hline LAL & 15.1 & $19.6 \pm 1.78$ & 24.1 & 76 & 17.4 & $20.0 \pm 1.22$ & 23.1 & 73 \\
\hline LPL & 26.7 & $35.3 \pm 3.06$ & 41.4 & 76 & 30.6 & $35.9 \pm 2.18$ & 41.1 & 73 \\
\hline $\mathrm{T} \mathrm{L}$ & 75.8 & $114.7 \pm 18.62$ & 150.2 & 50 & 86.2 & $120.2 \pm 12.36$ & 149.6 & 52 \\
\hline TBW & 4.4 & $6.8 \pm 0.83$ & 8.1 & 40 & 5.5 & $6.8 \pm 0.84$ & 9.0 & 37 \\
\hline MA & 3.0 & $3.0 \pm 2.02$ & 11.3 & 75 & 4.2 & $8.4 \pm 2.12$ & 13.5 & 72 \\
\hline NFP & 16 & $20.1 \pm 1.48$ & 24 & 76 & 16 & $20.2 \pm 1.62$ & 25 & 73 \\
\hline
\end{tabular}



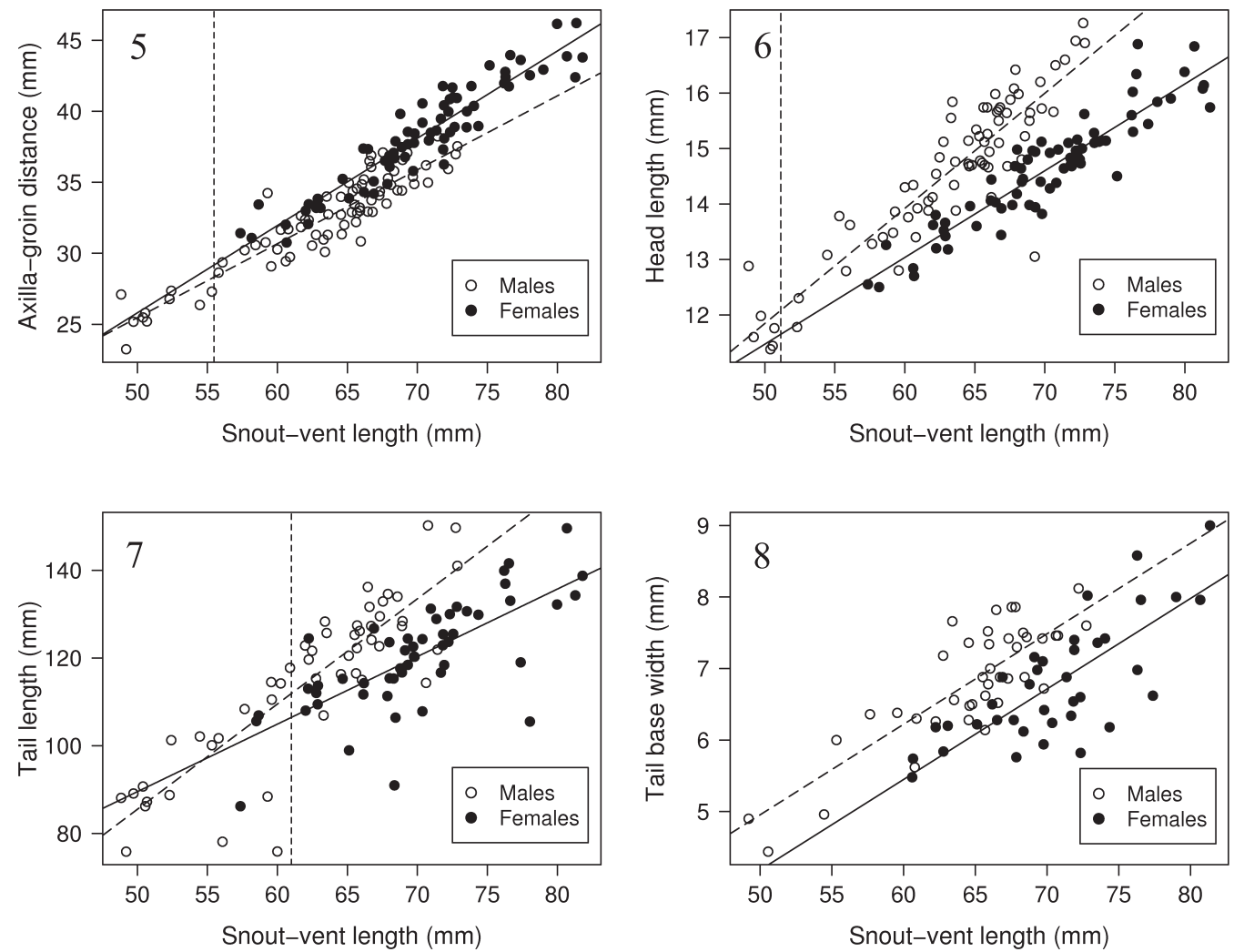

Figs. 5-8. Linear models relating selected morphometric variables to snout-vent length (SVL) and sex, Cnemidophorus vacariensis Feltrim \& Lema, 2000, August 2004 to August 2006, Vacaria, southern Brazil: 5, distance between axilla and groin (AG) by SVL and sex 6, head length (HL) by SVL and sex; 7, tail length (TL) by SVL and sex; 8, tail base width (TBW) by SVL and sex. Continuous straight lines: females; dashed lines: males. In graphs 5, 6, and 7, the region to the right of the vertical dotted line is that where the dependent variable is significantly different between sexes for each SVL, according to the Johnson-Neyman method. Equations of the lines: 5 , females, $\mathrm{AG}=0.6149 \mathrm{xSVL}-4.940$; males, $\mathrm{AG}=0.5208 \mathrm{xSVL}-0.575 ; 6$, females, $\mathrm{HL}=0.1563 \mathrm{xSVL}+3.655 ;$ males, $\mathrm{HL}=0.2075 \mathrm{xSVL}$ $+1.470 ; 7$, females, $\mathrm{TL}=1.5400 x \mathrm{xVL}+12.518$; males, $\mathrm{TL}=2.3999 \mathrm{xSVL}-34.497 ; 8$, females, $\mathrm{TBW}=0.1265 \mathrm{xSVL}-2.144 ;$ males, $\mathrm{TBW}=0.1265 \mathrm{xSVL}-1.372$.

With regard to differences in color, $88.1 \%(n=42)$ of the males presented yellow scales in the first and second ventral longitudinal rows; males with that coloration were observed throughout the year, that is, they were not found just during the reproductive period. All juveniles and all adult females presented the scales in that location in white color, as found on the belly.

\section{DISCUSSION}

Reproductive cycle. The available data indicate that C. vacariensis has a seasonal and discontinuous reproductive cycle, as it has been found for other lizard species that inhabit regions with seasonal climatic factors (precipitation and/or temperature) (e.g. MAGNUSSON, 1987).

In males, a peak of activity around November followed by a quiescent period between January and August forms a reproductive pattern similar to that found in males of Liolaemus occipitalis Boulenger, 1885 (Liolaemidae), a lizard that is found in the state of Rio Grande do Sul and inhabits coastal dunes (VERRASTRO \& KraUSE, 1999). The observed pattern is in agreement with the kind of pattern expected for reptiles in temperate zones (MARION, 1982).

The maximum testicular volume and the peak of female reproductive activity occurred a little before the peaks in temperature and photoperiod. MARION (1982) suggested that there is a strong association between temperature and testicular volume in Sceloporus undulatus (Bosc \& Daudin, 1801). In temperate regions, temperature and photoperiod are closely related. According to LichT \& GORMAN (1970), temperature and photoperiod, or a combination of both environmental factors, seem to stimulate gonadal activity in males from temperate regions. The necessity that reproduction should occur around the most favorable moment of time for the incubation of the eggs could be another possible explanation for the observed close association between reproductive activity and temperature. No association was observed between reproductive activity and precipitation. In tropical regions, precipitation is the main seasonal factor associated with lizard reproduction (e.g. Magnusson, 1987).

Although no mark and recapture techniques were applied in the present study, the seasonal distribution of SVLs suggests that animals were sexually mature in the first reproductive season after hatching.

Fat bodies cycle. FB mass varied in a cyclic way over the months in both sexes. Both males and females store lipids after the reproductive season, similarly to other lizards from temperate regions (DERICKSON, 1976a), and use the stored energy mainly at the beginning of the 
reproductive activity. This fact suggests an inverse association with the spermatogenesis and vitellogenesis processes, and is in agreement with results found by DERICKSON (1976a). FB cycles related to gonadal activity were documented for other lizard species (e.g. HAHN \& Tinkle, 1965), however in other species no apparent correlation may exist between the size of FBs and gonadal development (e.g. MAGnusson, 1987). Lipid reserves may be associated not only to reproduction, but also to body maintenance during cold or hibernating periods (CRUZ et $a l ., 1999$ ) or to a decrease in food resources (DERICKSON, 1976a). The activity and presence of individuals of $C$. vacariensis with stomachs filled with prey during the whole year (M. Schossler, pers. comm.) indicate that the food resources of this species are not limited and that it does not have hibernation periods, which gives support to the idea of association between FBs and reproductive activity in that species. Similarly to what has been found in other studies (HAHN \& TINKLE, 1965; DEARING \& Schall, 1994), females accumulated more fat than males.

Size and relative clutch mass. Clutch size in Cnemidophorus typically increases with SVL, and species with higher SVL tend to have larger clutches (VITT, 1983). However, some Cnemidophorus species have relatively high SVL values and very small clutch sizes (one to two eggs) (e.g. DEARING \& Schall, 1994). Small clutch sizes have been associated with predation, with the energetic cost of carrying eggs (especially for species that forage actively) (VITT \& BREITENBACH, 1993), and with the selection for larger relative size (resulting in higher competitiveness) of the hatchling in an environment poor in resources and/or with competitors of relatively small size (Colli et al., 2003). Clutch size in $C$. vacariensis is relatively large when compared to other species of Cnemidophorus with similar SVL (VITT \& BREITENBACH, 1993: fig. 2). When resources are abundant, adults may increase their fitness by spending less energy per hatchling, which could result in the production of more hatchlings per clutch, on the assumption that the number of hatchlings that survive will be higher the larger the number of hatchlings per clutch is (DERICKSON, 1976b). This suggests that resources are not limited for $C$. vacariensis females.

Two variables play an important role when analyzing the female reproductive effort: relative clutch mass and size of hatchlings. Selection for relative clutch mass should be related to the selection of female's morphology as a whole, while selection for clutch size should be related to the selection of optimum size of hatchlings. According to ViTT \& BREITENBACH (1993), the way the reproductive investment should be divided (either a large number of small eggs or a small number of large eggs) is a consequence of the differential survivorship of hatchlings based on their size, where the nature of the environment determines the optimum size of the hatchling.

The inverse relationship between the duration of the reproductive season and clutch size has been documented for lizards (e.g. PianKa, 1970). Apparently, species living in high latitudes, where environmental conditions favorable for copulation, oviposition, hatching and growth of hatchlings are usually available for only a few months, tend to show seasonal reproduction with a definite reproductive peak and a relatively small number of clutches with a larger number of eggs each. The production of two clutches per year in $C$. vacariensis is in accord with what has been found for other species in the genus, and it could be associated with the duration of the reproductive season (VITT \& BREITENBACH, 1993).

PIANKA \& VITT (2003) observed that, for species with low population density, there is a low level of interaction among males, and females tend to produce clutches with a larger number of eggs; in that case, selection would favor a larger female size. However, that hypothesis seems not to apply to $C$. vacariensis in the study area, since that lizard seems to be relatively abundant when compared to other local species. During the study period, we found individuals of Cercosaura schereibersii Wiegmann, $1834(\mathrm{n}=8)$, Mabuya dorsivittata Cope, $1862(\mathrm{n}=6)$, Ophiodes sp. $(\mathrm{n}=1)$, Tupinambis merianae (Dumèril \& Bibron, 1839) $(\mathrm{n}=2)$, and Anisolepis grilli Boulenger, $1891(\mathrm{n}=1)$ living sympatrically with $C$. vacariensis $(\mathrm{n}=249)$.

Relative clutch mass could partly reflect the influence of foraging habit on the morphological evolution of lizard species; relative clutch mass is generally low for active foragers and high for sit-andwait ones (VITT \& Congdon, 1978; VitT \& Price, 1982). In the majority of Cnemidophorus, relative clutch mass ranges between 0.11 and 0.21 (VITT \& BREITENBACH, 1993), but for some species the total mass is at most divided between two large eggs, while for other species it is divided among four to five smaller eggs. However, VITT \& BREITENBACH (1993) pointed out the problem of the quality of the data on relative clutch mass; this may include the way that data are collected, small sample sizes, and the considerable change in egg mass between ovulation and oviposition. Relative clutch mass for $C$. vacariensis is within the limits which have been found for that genus. However, taking into account the different developmental stages of eggs found in the oviducts, the value of 0.22 found for $C$. vacariensis seems to represent the developmental stage closest to oviposition. The small sample size makes it difficult to draw any conclusion from that data. However, if we assume that the relative mass is close to the upper limit expected for the genus, another hypothesis about the large clutch size and high relative mass can be formulated: on a scale between sit-and-wait and active foraging behavior, $C$. vacariensis is possibly on the less active side, closer to the sit-and-wait behavior, as suggested by ANJos et al. (2002) for Kentropyx paulensis Boettger, 1893. Even though Cnemidophorus species have been characterized as active foragers, we did not observe any animals with that kind of behavior. The analysis of stomach contents (M. Schossler, pers. comm.) revealed that this lizard feeds mainly on spiders, grasshoppers and cockroaches, arthropods with a certain degree of movement. Potential sedentary preys, for example coleopteran larvae, were only found in the stomachs of a few males in the spring, and termites were found neither in males nor in females, although there were plenty of them in the environment.

Sexual dimorphism. Adult females of $C$. vacariensis had a higher mean and a higher maximum SVL than adult 
males. However, in the majority of the species of Teiidae, males are generally larger than females (ANDERSON \& VitT, 1990). Similarly to Cnemidophorus ocellifer (Spix, 1825) (VITT, 1983), females of $C$. vacariensis tend to produce a larger clutch the larger their SVL is; presumably, this confers a selective advantage to the increase in SVL. Observations on the fighting behavior for access to females and on the mating behavior of males in Teiidae suggest that selection should favor a larger size for males due to higher chances of winning intrasexual combats and mating with females (ANDERSON \& VITT, 1990). On the assumption that there is no direct competition among males, it is to be expected that females should be larger than males (VITT, 1983). For C. vacariensis, we observed neither scars possibly originating from bites and fights nor fighting behavior among males, which suggests that fights between males are absent or very rare. On four occasions we found two individuals under one same stone. On two of these occasions we found one male and one female, both in the reproductive period (November and December); on the other two occasions, both in August, an adult female and an immature male, and two adult males, were found. Moreover, if we take into account the apparent fact that $C$. vacariensis has a less intense foraging activity (diet analysis suggests a low foraging activity - see the explanation above), maybe the patchy environment leads to a decrease in encounters with other individuals.

The environment where this lizard lives is composed of evenly spaced rocky outcrops distributed over a grassland area. On the assumption that individuals forage most of the time under the stones and spend most of their lives in that protected microhabitat, displacement and predation rates should be different between males and females; they should be higher in males due to movements linked to reproductive activity. This should lead to selection for smaller body size in males, which would make them more mobile (SHINE, 1988) and would allow them to reproduce earlier in life, so saving time and energy in their search for reproductive females (Cox et $a l ., 2003)$. On the other hand, the lower displacement rate of females and the consequent lower predation rate should favor an increase in their body size. Mark and recapture studies to get information on the home range and habitat usage of these animals are necessary.

According to SHINe (1989), the difficulty in understanding the causes of sexual dimorphism stems in large part from the fact that the processes of fecundity selection, sexual selection and ecological divergence may act on the same taxon. Sexual dimorphism in body size could potentially develop in response to any of these selective forces, acting either in isolation or in a combined way, in that last case acting either simultaneously or sequentially in time. The point is to investigate whether selection is acting either in favor of a decrease in males' size or in favor of an increase in females' size, or towards a combination of these cases. Although it is not clear how selection is acting to generate the observed pattern of male-female sizes, it is possible that the dimorphism observed in C. vacariensis is a derived character, since that pattern is unknown in the family Teiidae.
Sexual dimorphism in head length in males has been attributed to sexual selection (CAROTHERS, 1984) or to a difference in diet between sexes (SCHOENER, 1967); the sexual dimorphism in distance between axilla and groin has been attributed to fecundity selection in females (Olsson et al., 2002). These two measurements are complementary in relation to the SVL of the animal, so they seem not to be independent, and consequently one should be careful when trying to explain the causes of dimorphism in these characteristics. VITT (1983) pointed out that the difference in prey size could be the consequence of the size dimorphism between sexes, and not its cause. However, there is no intersexual difference in prey size in C. vacariensis (M. Schossler, pers. comm.), so sexual dimorphism is not associated with a differential use of food resources. There is sexual dimorphism in the size of the head of most Teiidae (ANDERson \& VitT, 1990), so it is likely that the sexual dimorphism in head size in $C$. vacariensis may be a plesiomorphic character.

In studies with snakes, SHINE et al. (1999) observed that males with longer tails have longer hemipenis and are more successful in mating than individuals with partial tail loss. As observed in snakes, in males of $C$. vacariensis longer and wider tails could be associated with the size of the copulatory organ and with reproductive success.

Sexual dimorphism in the coloration of the first and second rows of ventral longitudinal scales in the abdomen is probably associated with sexual maturation in males, since juveniles and females always presented white scales. Feltrim (2002) suggested that sexual dimorphism in coloration could represent a social sign and could play an important role in sexual recognition.

Conservation. Cnemidophorus vacariensis is probably at risk of significant reduction in population size, or even possibly at risk of extinction in a relatively short period of time, due to the increasing degradation of its habitat caused by plantation and ranching, as that habitat is entirely within private lands. Some possible measures for the protection of $C$. vacariensis and its environment include (1) the creation of conservation areas, especially under the title "Private Reserves of the Natural Heritage" ("Reservas Particulares do Patrimônio Natural"), one of the categories of "Areas of Sustainable Use" in the Brazilian system of nature reserves, (2) to stimulate owners of private lands, possibly through some kind of compensation, to keep at least part of their lands in pristine condition, especially those areas with a high density of C. vacariensis, and (3) the maintenance of ecological corridors connecting preserved areas. We believe that a continuous monitoring of the $C$. vacariensis population and its habitat should be performed, in order to obtain time-dependent information that would allow the proper continued assessment of the conservation status of the population and its environment and also the assessment of conservation measures.

Acknowledgments. We would like to especially thank Mr. F. Branco for allowing this research to be carried out on his property. We also thank Dr. M. Borges-Martins, Dr. C. F. D. Rocha, and Dr. R. B. Oliveira for valuable suggestions that helped us to improve this article, and M. L. M. Alves for critical reading of the manuscript. We thank Dr. L. J. Vitt for helpful exchange of ideas 
and suggestions concerning this research. The manuscript has been improved through suggestions by two referees; our thanks to them. The project "Ecologia de Lagartos do Sul do Brasil" was financially supported by $\mathrm{CNPq}$, and F. M. Rezende-Pinto was granted a graduate scholarship by CAPES.

\section{REFERENCES}

Anderson, R. A. \& VitT, L. J. 1990. Sexual selection versus alternative causes of sexual dimorphism in teiid lizards. Oecologia 84:145-157.

Anjos, L. A.; Kiefer, M. C. \& Sawaya, R. J. 2002. Kentropyx paulensis. Reproduction. Herpetological Review 33(1):52.

Ballinger, R. E. 1983. Life-history variations. In: Huey, R. B.; Pianka, E. R. \& Schoener, T. W. eds. Lizard Ecology: studies of a model organism. Cambridge, Harvard University. p.241-260.

Bérnils, R. S.; Moura-Leite, J. C. \& Morato, S. A. A. 2004 Répteis. In: МiкICH, S. B. \& Bérnils, R. S. eds. Livro vermelho da fauna ameaçada do Estado do Paraná. Curitiba, Instituto Ambiental do Paraná. p.497-536.

BoldRINI, I. I. 1997. Campos do Rio Grande do Sul: caracterização fisionômica e problemática ocupacional. Boletim do Instituto de Biociências 56:1-39.

Carothers, J. H. 1984. Sexual selection and sexual dimorphism in some herbivorous lizards. The American Naturalist 124(2):244-254

Cleveland, W. S.; Grosse, E. \& Shyu, W. M. 1993. Local regression models. In: Chambers, J. M. \& Hastie, T. J. eds. Statistical Models in S. London, Chapman \& Hall. p.309-376.

Colli, G. R.; Caldwell, J. P.; Costa, G. C.; Gainsbury, A. M.; Garda, A. A.; Mesquita, D. O.; Filho, C. M. M. R.; Soares, A. H. B.; Silva, V. N.; Valdujo, P. H, Vieira; G. H. C.; VitT, L. J.; Werneck, F. P.; WiederheCKer, H. C. \& Zatz, M. G. 2003. A new species of Cnemidophorus (Squamata, Teiidae) from the Cerrado Biome in Central Brazil. Occasional Papers of the Oklahoma Museum of Natural History 14:1-14.

Cox, R. M.; Skelly, S. L. \& John-Alder, H. B. 2003. A comparative test of adaptative hypotheses for sexual size dimorphism in lizards. Evolution 57(7):1653-1669.

Cruz, F. B.; Teisaire, E.; Nieto, L. \& Roldán, A. 1999. Reproductive biology of Teius teyou in the Semiarid Chaco of Salta, Argentina. Journal of Herpetology 33(3):420-429.

Dearing, M. D. \& Schall, J. J. 1994. Atypical reproduction and sexual dimorphism of the tropical Bonaire Island whiptail lizard, Cnemidophorus murinus. Copeia 1994:760-766.

Derickson, W. K. 1976a. Lipid storage and utilization in reptiles. American Zoologist 16:711-723.

Derickson, W. K. 1976b. Ecological and physiological aspects of reproductive strategies in two lizards. Ecology 57:445-458.

Di-Bernardo, M.; Borges-Martins, M. \& Oliveira, R. B. 2003. Répteis. In: Fontana, C. S.; Bencke, G. A. \& Reis, R. E. eds. Livro vermelho da fauna ameaçada de extinção no Rio Grande do Sul. Porto Alegre, EDIPUCRS. p.165-188.

Dunham, A. E. \& Miles, D. B. 1985. Patterns of covariation in life history traits of squamate reptiles: the effect of size and phylogeny reconsidered. The American Naturalist 126(2):231-257

Feltrim, A. C. 2002. Dimorfismo sexual em Cnemidophorus lacertoides (Squamata, Teiidae) do sul da América do Sul. Phyllomedusa 1(2):75-80.

Fortes, A. B. 1959. Geografia do Rio Grande do Sul. Porto Alegre, Globo. 393p

Hahn, W. E \& Tinkle, D. W. 1965. Fat body cycling and experimental evidence for its adaptative significance to ovarian follicle development in the lizard Uta stansburiana. The Journal of Experimental Zoology 158:79-86.

Huey, R. B. \& Pianka, E. R. 1981 Ecological consequences of foraging mode. Ecology 62(4):991-999.

Instituto Brasileiro do Meio Ambiente e dos Recursos Naturais Renováveis. 2003. Lista Nacional das Espécies da Fauna Brasileira Ameaçada de Extinção. Available at: <http:// www.ibama.gov.br/fauna/downloads/lista\%20spp.pdf>. Access on: 09.01 .2007

Johnson, R. A. \& Wichern, D. W. 2002. Applied multivariate statistical analysis. 5ed. Upper Saddle River, Pearson Prentice Hall. $767 \mathrm{p}$.
Licht, P. \& Gorman, G. C. 1970. Reproductive and fat cycle in Caribbean Anolis lizards. University of California Publications in Zoology 95:1-52.

Magnusson, W. E. 1987. Reproductive cycles of teiid lizards in Amazonian Savanna. Journal of Herpetology 21(4):307-316.

Maluf, J. R. T. 2000. Nova classificação climática do Estado do Rio Grande do Sul. Revista Brasileira de Agrometeorologia 8(1):141-150.

Marion, K. R. 1982. Reproductive cues for gonadal development in temperate reptiles: temperature and photoperiod effects on the testicular cycles of the lizard Sceloporus undulatus. Herpetologica 38(1):26-39.

Marques, A. A. B.; Fontana, C. S.; Vélez, E.; Bencke, G. A.; Schneider, M. \& Reis, R. E. 2002. Lista das Espécies de Fauna Ameaçadas de Extinção no Rio Grande do Sul Decreto $\mathrm{n}^{\circ}$ 41.672, de 11 de junho de 2002. Porto Alegre, FZBRS/MCT-PUCRS/PANGEA. 52p.

Olsson, M.; Shine, R.; Wapstra, E.; Ujvari, B. \& Madsen, T. 2002 Sexual dimorphism in lizard body shape: the role of sexual selection and fecundity selection. Evolution 56(7):15381542 .

Pianka, E. R. 1970. Comparative autoecology of the lizard Cnemidophorus tigris in different parts of its geographic range. Ecology 51(4):703-720.

Pianka, E. R. \& VitT, L. J. 2003. Lizards: windows to the evolution of diversity. Berkeley, University of California. $333 \mathrm{p}$.

Роттноғ,, R. F. 1983. Johnson-Neyman technique. In: Kotz, S. \& Johnson, N. L. eds. Encyclopedia of Statistical Sciences. New York, Wiley. v.4, p.299-303.

$R$ Development Core Team. 2006. R: A language and environment for statistical computing. Vienna, $R$ Foundation for Statistical Computing. Available at: <http:// www.R-project.org> Access on: 22.12.2006.

Reeder, T. W.; Cole, C. J. \& Dessauer, H. C. 2002. Phylogenetic relationships of whiptail lizards of the genus Cnemidophorus (Squamata: Teiidae): a test of monophyly, reevaluation of karyotypic evolution, and review of hybrid origins. American Museum Novitates 3365:1-61

Reist, J. 1985. An empirical evaluation of several univariate methods that adjust for size variation in morphometric data Canadian Journal Zoology 63:1429-1439.

Schoener, T. W. 1967. The ecological significance of sexual dimorphism in size in the lizard Anolis conspersus. Science 155:474-476

Shine, R. 1988. The evolution of a large body size in females: a critique of Darwin's "fecundity advantage" model. The American Naturalist 131(1):124-131.

1989. Ecological causes for the evolution of sexual dimorphism: a review of the evidences. The Quarterly Review of Biology 64(4):419-461.

Shine, R.; Olsson, M. M.; Moore, I. T.; LeMaster, M. P. \& Mason, R. T. 1999. Why do male snakes have longer tails than females? Proceedings of the Royal Society of London 266:2147-2151

Sociedade Brasileira de Herpetologia. 2005. Lista de espécies de répteis do Brasil. Sociedade Brasileira de Herpetologia (SBH). Available at: <http://www2.sbherpetologia.org.br/ checklist/repteis.htm>. Access on: 09.01.2007.

StahnKe, L. F.; Silva, G. E. F.; Reguly, R. S. \& Machado, I. F. 2006 Novo registro de Cnemidophorus vacariensis para o estado do Rio Grande do Sul, Brasil (Sauria, Teiidae). Biociências 14(1):91-92.

U. S. Naval Observatory (Astronomical Applications Department) 2007. Data Services, Duration of Daylight/Darkness Table for One Year. Available at: 〈http://aa.usno.navy.mil>. Access on: 15.11 .2006

Verrastro, L. \& Krause, L. 1999. Ciclo reprodutivo de machos de Liolaemus occipitalis Boulenger (Sauria, Tropiduridae) Revista Brasileira de Zoologia 16(1):227-231.

VERZANI, J. 2005. Using $\mathbf{R}$ for introductory statistics. Boca Raton, Chapman \& Hall/CRC. 414p.

VitT, L. J. 1983. Reproduction and sexual dimorphism in the tropical teiid lizard Cnemidophorus ocellifer. Copeia 1983:359-366. 
1990. The influence of foraging mode and phylogeny on seasonality of tropical lizard reproduction. Papéis Avulsos de Zoologia 37(6):107-123.

VitT, L. J. \& BReitenBach, G. L. 1993. Life histories and reproductive tactics among lizards in the genus Cnemidophorus (Sauria: Teiidae). In: Wright, J. W. \& VItT, L. J. eds. Biology of whiptail lizards (Genus Cnemidophorus). Norman, Oklahoma Museum of Natural History. p.211-244.

VitT, L. J. \& Congdon, J. D. 1978. Body shape, reproductive effort, and relative clutch mass in lizards: resolution of paradox. The American Naturalist 112(985):595-608 .
Vitt, L. J. \& Price, H. J. 1982. Ecological and evolutionary determinants of relative clutch mass in lizards. Herpetology 38:237-255.

Wood, S. N. 2006. Generalized Additive Models: an introduction with R. Boca Raton, Chapman \& Hall/CRC. $416 \mathrm{p}$.

Wright, J. W. 1993. Evolution of the lizards of the genus Cnemidophorus. In: Wright, J. W. \& Vitt, L. J. eds. Biology of whiptail lizards (Genus Cnemidophorus). Norman, Oklahoma Museum of Natural History. p.27-81.

Recebido em julho de 2007. Aceito em agosto de 2008. ISSN 0073-4721

Artigo disponível em: www.scielo.br/isz 